\title{
TOXICITY OF ZINC TO HETEROTROPHIC BACTERIA FROM A TROPICAL RIVER SEDIMENT
}

\author{
C. O. NWEKE ${ }^{1, *}$ - C. S. ALISI ${ }^{2}-$ J.C. OKOLO ${ }^{1}$ - C. E. NWANYANWU ${ }^{1}$ \\ ${ }^{1}$ Department of Microbiology, Federal University of Technology, P.M.B.1526, Owerri, Nigeria. \\ ${ }^{2}$ Department of Biochemistry, Federal University of Technology, P.M.B. 1526, Owerri, \\ Nigeria. \\ e-mail:xrisokey@yahoo.com \\ (Received 31 $1^{\text {th }}$ Jan 2007; accepted $15^{\text {th }}$ May 2007)
}

\begin{abstract}
Tolerance to $\mathrm{Zn}^{2+}$ by pure cultures of Bacillus, Salmonella and Arthrobacter species isolated from New Calabar River sediment was assessed through dehydrogenase assay. The cultures were exposed to $\mathrm{Zn}^{2+}$ concentrations of 0.2 to $2.0 \mathrm{mM}$ in a nutrient broth-glucose-TTC medium. The responses of the bacterial strains varied with $\mathrm{Zn}^{2+}$ concentration. In Salmonella sp. SED2, $\mathrm{Zn}^{2+}$ stimulated dehydrogenase activity at $0.2 \mathrm{mM}$. In Bacillus sp. SED1 and Arthrobacter sp. SED4, dehydrogenase activity was progressively inhibited with increasing $\mathrm{Zn}^{2+}$ concentration. The $\mathrm{IC}_{50}$ ranges from $0.206 \pm 0.030$ to 0.807 $\pm 0.066 \mathrm{mM}$. Total inhibition of dehydrogenase activity was observed at concentrations ranging from $1.199 \pm 0.042$ to $1.442 \pm 0.062$. The order of zinc tolerance is: Salmonella sp. SED2 > Arthrobacter sp. SED4 > Bacillus sp. SED1. The result of the in vitro study indicated that Zinc is potentially toxic to sediment bacteria and could pose serious threat to their metabolism in natural environments.
\end{abstract}

Keywords: dehydrogenase activity, sediment bacteria, New Calabar River.

\section{Introduction}

Bacteria and other microorganisms densely colonize freshwater and marine sediments. In these environments, bacteria constitute the primary agents of early transformation of organic matter and regeneration of nutrients and also serve as food source for higher trophic level.

Microorganisms are vital for the efficient functioning of any ecosystem, hence factors that affect their metabolism, composition and abundance are of great concern. Monitoring microbial responses has been recommended as an early warning indicator of ecosystem stress as microbes respond promptly to environmental perturbations $[12,29]$. Measurement of microbial enzyme activity is used in the assessment of ecotoxicological impacts of environmental substrates. In this regard, dehydrogenase activity has been widely used. The dehydrogenase assay is an effective primary test for assessing the potential toxicity of metals to soil microbial activities $[1,7,18,31]$ and bioavailability of metal in a beach sediment [9].

The pollution of New Calabar River is due to anthropogenic activities along its bank $[25,27,28]$. The heavy metal content, seasonal variations in the population of heavy metal resistant bacteria and toxicity of heavy metals to bacteria isolated from the New Calabar River have been reported [23, 25, 26]. Moreso, Odokuma and Abah reported bioaccumulation of selected heavy metals by bacteria isolated from this river [24]. Although, these works focused on pure cultures of bacterial isolates, they did not consider the inhibition of dehydrogenase enzyme activity in these bacteria. This study was aimed at assessing the effects of zinc on the dehydrogenase activities of Bacillus, Salmonella and Arthrobacter species isolated from New Calabar River sediment. 


\section{Materials and methods}

\section{Sample collection and analysis}

The New Calabar River is a short tidal coastal river of about 150-200 km in length and is situated in the Niger delta of Nigeria. The water is brackish and impacted by effluent discharges from industries sited along its bank. The sampling site have been described elsewhere [26, 27]. Sediment and water samples were collected along the course of the river at Choba. Eckman grab sampler was used for collection of sediment sample. The overlying water sample was collected midstream along the course of the river from a depth of $30 \mathrm{~cm}$. The samples were collected in sterile glass bottles, stored in a cooler and taken to laboratory. All samples were analysed within 6 hours of collection. The $\mathrm{pH}$ and zinc content of the samples were determined using $\mathrm{pH}$ meter (Jenway 3015) and atomic absorption spectrophotometer (Perkins Elmer 3110) respectively.

\section{Isolation of bacterial strains and culture conditions}

Aerobic heterotrophic bacteria in the New Calabar River sediment were isolated and purified on nutrient agar plates. Characterizations were done using standard microbiological methods. Identifications to the generic level followed the schemes of Holt et al. [13].

The bacterial strains were grown to mid exponential phase in nutrient broth (Lab M) on a rotary incubator $(150 \mathrm{rpm})$ at room temperature $\left(28 \pm 2{ }^{\circ} \mathrm{C}\right)$. The cells were harvested by centrifugation at $4000 \mathrm{rpm}$ for 10 minutes. Harvested cells were washed twice in deionized distilled water and resuspended in the same water. The resuspended cells were standardized in a spectrophotometer to an optical density of 0.85 at $420 \mathrm{~nm}$. The dry weights of the standardized cells were determined by drying $10 \mathrm{ml}$ of cell suspension to constant weight in an oven at $110^{\circ} \mathrm{C}$. These standardized cell suspensions were used as inoculum in the dehydrogenase activity assay.

\section{Dehydrogenase activity assay}

Dehydrogenase activity was determined using TTC as the artificial electron acceptor, which is reduced to the red-coloured TPF. The assay was done in 3-ml volumes of nutrient broth-glucose-TTC medium supplemented with varying concentrations $(0.2-$ $1.0 \mathrm{mM})$ of $\mathrm{Zn}^{2+}$ as zinc sulphate in separate $20 \mathrm{ml}$ screw-capped test tubes. Portions $(0.3 \mathrm{ml})$ of the bacterial suspensions were inoculated into triplicate glass tubes containing $2.5 \mathrm{ml}$ of phthalate-buffered ( $\mathrm{pH} \mathrm{6}$ ) nutrient broth-glucose medium amended with $\mathrm{Zn}^{2+}$ and preincubated on a rotary incubator $(150 \mathrm{rpm})$ at room temperature $(28 \pm 2$ $\left.{ }^{\circ} \mathrm{C}\right)$ for $30 \mathrm{~min}$. Thereafter, $0.2 \mathrm{ml}$ of $0.4 \%(\mathrm{w} / \mathrm{v})$ TTC in deionized distilled water was added to each tube to obtain final $\mathrm{Zn}^{2+}$ concentrations of $0.2,0.4,0.6,0.8$ and $1.0 \mathrm{mM}$ in different test tubes. The final concentrations of nutrient broth, glucose and TTC in the medium were 2,2 and $0.267 \mathrm{mg} / \mathrm{ml}$ respectively. The controls consisted of the isolates and the media without $\mathrm{Zn}^{2+}$. The reaction mixtures were further incubated statically at room temperature $\left(28 \pm 2{ }^{\circ} \mathrm{C}\right)$ for $4 \mathrm{~h}$. The TPF produced were extracted in $4 \mathrm{ml}$ of amyl alcohol and determined spectrophotometrically at $445 \mathrm{~nm}(\lambda \max )$. The amount of formazan produced was determined from a standard dose-response curve $[0-50 \mathrm{mg} / 1$ TPF (Sigma) in amyl alcohol; $\left.\mathrm{R}^{2}=0.996\right]$. Dehydrogenase activity was expressed as milligrams of TPF formed per mg dry weight of cell biomass per hour. 
Zinc inhibition of dehydrogenase activity was calculated relative to the control. The percentage inhibitions for Bacillus and Arthrobacter species were linearized against the concentrations of $\mathrm{Zn}^{2+}$ using gamma parameter (Г) as shown in the equation below [19]. The toxicity threshold concentrations $\left(\mathrm{IC}_{20}\right.$ and $\mathrm{IC}_{50}$ ) were then determined from regression plots. The total inhibitory concentrations $\left(\mathrm{IC}_{100}\right)$ were estimated from the linear regressions of log transformation plots of the dose-response data.

Inhibition of dehydrogenase activities in the sediment bacteria was compared with that of planktonic bacteria isolated from New Calabar River water.

$$
\Gamma=\frac{\% \text { Inhibition }}{100-\% \text { Inhibition }}
$$

\section{Statistical analysis}

Data generated were subjected to multiple factor analysis of variance (2-Way ANOVA).

\section{Results and discussion}

The sediment is slightly acidic $(\mathrm{pH}$ 6.62) and has elevated zinc concentrations of $65.8 \mathrm{mg} / \mathrm{kg}$ sediment. The $\mathrm{pH}$ and zinc content of the overlying river water were 6.4 and $5 \mathrm{mg} / 1(\approx 76.48 \mu \mathrm{M})$ respectively. The higher zinc content in the sediment could be attributed to incorporation of zinc into sediment following it's association with particulate matters. In an undisturbed environment, heavy metals are preferentially transferred from the dissolved phase and thus metal concentrations in sediments are generally much higher than in the overlying water [6]. Previously, zinc levels of 0.01 to $0.71 \mathrm{mg} / \mathrm{l}[24,25,26]$ in the river water and 31.18 to $32.02 \mathrm{mg} / \mathrm{kg}$ [15] in the sediment of New Calabar River was reported. This indicated that zinc was accumulating in the New Calabar River water and sediment over time.

Three predominant bacterial strains comprising one Gram negative (Salmonella sp. SED2) and two Gram positive (Bacillus sp. SED1 and Arthrobacter sp. SED4) organisms were isolated from the river sediment. These isolates were able to reduce TTC to its formazan and so were used to assess toxicity of toxicant through dehydrogenase activity assay. Bacillus, Arthrobacter, Salmonella and Proteus species have been isolated from New Calabar River by Odokuma and Ijeomah [24, 25].

The rate of dehydrogenase activity varied among the bacterial strains (Table 1). The Gram positive Bacillus sp. SED1 had higher rates of dehydrogenase activity than the Gram negative Salmonella sp. SED2 and Gram positive Arthrobacter sp. SED4. In a similar study with planktonic bacteria of New Calabar River, Gram negative bacteria was reported to have higher rate of dehydrogenase activity than the Gram positive ones [23]. The reason for these differences is not known. However, it may be attributed to the physiology of the bacteria.

The effects of $\mathrm{Zn}^{2+}$ on the dehydrogenase activity and its relative inhibition in the bacterial strains are shown in Figure 1 and Table 2 respectively. In Bacillus sp. SED1 and Arthrobacter sp. SED4, dehydrogenase activity decreased with increasing concentration of $\mathrm{Zn}^{2+}$. In Salmonella sp. SED2, dehydrogenase activity was slightly stimulated at $0.02 \mathrm{mM} \mathrm{Zn}{ }^{2+}$ and progressively inhibited at concentrations greater than $0.2 \mathrm{mM}(0.4-1.0 \mathrm{mM})$. The stimulatory effect observed with Salmonella sp. SED2 


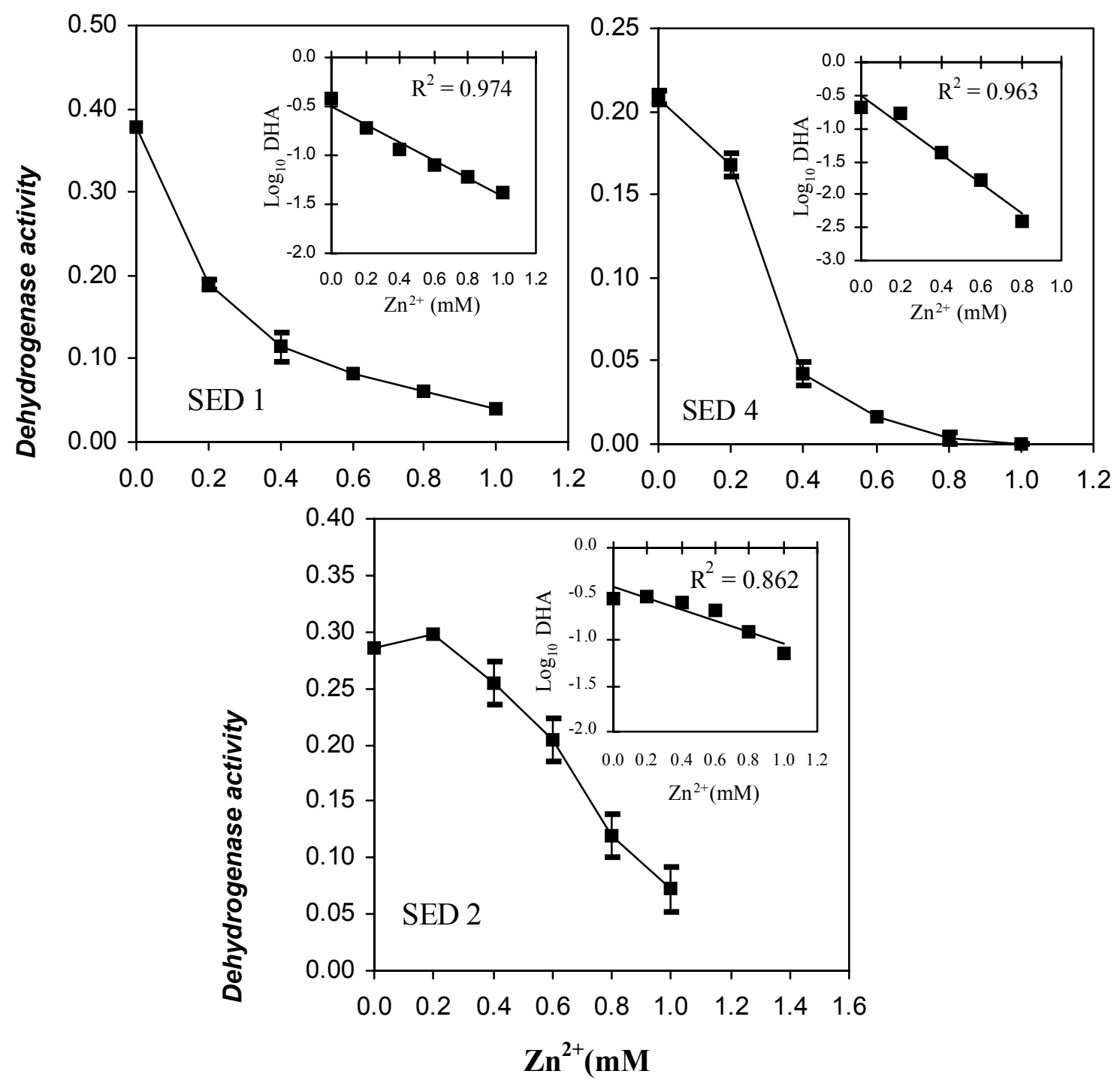

Figure 1. Dehydrogenase activity in response to various concentrations of zinc ion by Bacillus sp. SED1, Salmonella sp. SED2 and Arthrobacter sp. SED4. The vertical bars indicates mean \pm standard deviation ( $n=3)$. The figure insets show linear relationships between $\mathrm{Zn}^{2+}$ and mean dehydrogenase activity (DHA) in each bacterial strain

Table 1. Uninhibited dehydrogenase activities in the isolates

\begin{tabular}{lc}
\hline Strain & $\begin{array}{c}\text { Dehydrogenase activity } \\
\text { (mg Formazan/mg cell dry wt/h) }\end{array}$ \\
\hline & $0.379 \pm 0.038$ \\
Bacillus sp. SED1 & $0.208 \pm 0.004$ \\
Salmonella sp. SED2 & $0.285 \pm 0.002$ \\
Arthrobacter sp. SED4 & \\
\hline
\end{tabular}


may be attributed to the use of zinc as trace element by this bacterium. Zinc is associated with a number of processes essential for growth and metabolism in bacteria [8]. The inhibition of dehydrogenase activity observed in this study is consistent with the reported toxic effect of zinc at high concentrations [16]. Although zinc is an essential element, it is an inhibitor of respiratory activities in microorganisms $[3,17,30]$.

Results presented in Table 2 showed that the Gram negative Salmonella sp. SED2 tolerated zinc more than the Gram positive Bacillus sp. SED1 and Arthrobacter sp. SED4. Salmonella sp. SED2 had lower percentage inhibition of dehydrogenase activity at all concentrations of $\mathrm{Zn}^{2+}$. Better tolerance to heavy metal toxicity by Gram negative bacteria have been reported [20,21]. In comparison, there is no significant difference ( $p$ $<0.05$ ) between the percentages of inhibition of dehydrogenase activities in sediment and planktonic bacteria of New Calabar River. This did not corroborate reports that organisms isolated from heavy metal polluted habitats are more tolerant to metals than organisms isolated from unpolluted habitats. It could be that the concentration of zinc was not high enough to select for tolerant organisms in the sediment. The effects of zinc on the microbial activity of water and sediment communities have been reported [22, $23,32]$. A suppression of organic decomposition was observed in the heavy metal contaminated sediment of Palestine Lake containing average zinc level of $17840 \mathrm{mg} / \mathrm{kg}$ sediment [22]. Likewise, $\mathrm{Zn}^{2+}$ inhibited glucose uptake and mineralization by water and sediment microbial communities of a contaminated stream. A $10 \%$ reduction in the maximum rate of glucose uptake was obtained at lower metal concentrations in the water samples than in the sediment ones [32]. This indicates that water microbial community is more sensitive to metal toxicity than sediment community. Hornor and Hilt have made similar observations, where bacteria in polluted site are more tolerant to metal than those in unpolluted sediment [14]. Hornor and Hilt also observed that the presence of Zn-tolerant bacteria correlated with the degree of heavy metal contamination. Numerous other reports also revealed that bacteria isolated from environments with high levels of heavy metal exhibit greater metal tolerance than bacteria isolated from unpolluted habitats $[2,10,11,33]$.

The dehydrogenase activities correlated with $\mathrm{Zn}^{2+}$ concentration as shown in Figure 1 (insets). The high $\mathrm{R}^{2}$ values $\left(0.862 \leq \mathrm{R}^{2} \leq 0.974\right)$ indicated that $\mathrm{Zn}^{2+}$ concentration was a strong determinant of dehydrogenase activities in the organisms. Thus, the organisms are at serious stress at high concentrations of $\mathrm{Zn}^{2+}$.

The gamma parameter model gave good linearization of the dose response data for Bacillus sp. SED1 $\left(0.987 \leq \mathrm{R}^{2} \leq 0.994\right)$ and Arthrobacter sp. SED4 $\left(0.976 \leq \mathrm{R}^{2} \leq\right.$ 0.993). However, for Salmonella sp. SED2, the response (percentage inhibition) is linear $\left(0.970 \leq \mathrm{R}^{2} \leq 0.993\right)$ with the concentrations of $\mathrm{Zn}^{2+}$ and does not require linearization process (Figure 2). Table 3 shows the toxicity threshold concentrations $\left(\mathrm{IC}_{20}, \mathrm{IC}_{50}\right.$ and $\left.\mathrm{IC}_{100}\right)$ of $\mathrm{Zn}^{2+}$ estimated from the linear regression models. Bacillus sp. SED1 having the least $\mathrm{IC}_{20}$ and $\mathrm{IC}_{50}$ of 0.071 and $0.206 \mathrm{mM}$ respectively was the most sensitive to $\mathrm{Zn}^{2+}$ while Salmonella sp. SED1 having the highest $\mathrm{IC}_{20}$ and $\mathrm{IC}_{50}$ of 0.488 and $0.807 \mathrm{mM}$ respectively was the most tolerant. Using INT-dehydrogenase activity assay, Pérez-Garcia and co-workers reported an $\mathrm{IC}_{20}$ and $\mathrm{IC}_{50}$ of 0.999 and $2.88 \mathrm{mM}$ of $\mathrm{Zn}^{2+}$ against Pseudomonas fluorescens [30]. In a MetPLATE TM assay system (based on $\beta$-galactosidase activity), zinc $\mathrm{IC}_{50}$ of $0.11 \pm 0.001 \mathrm{mg} / 1(0.002 \mathrm{mM})$ was reported for Escherichia coli [5]. In a growth inhibition test assessed via turbidity measurements, $7.15 \mathrm{mg} / 1 \mathrm{Zn}^{2+}(0.12 \mathrm{mM})$ inhibited the growth of Pseudomonas putida by $50 \%$ [34]. In 


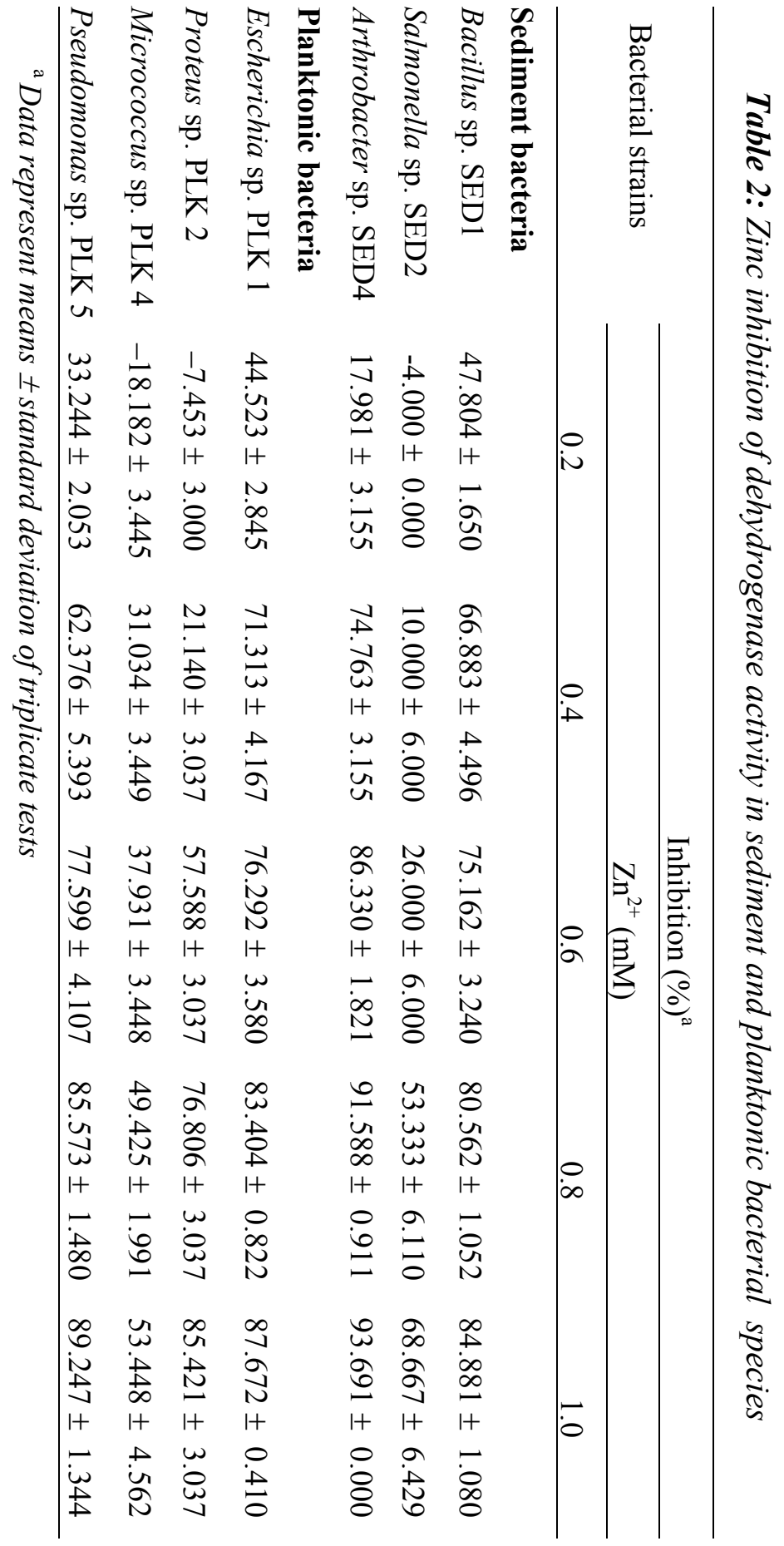



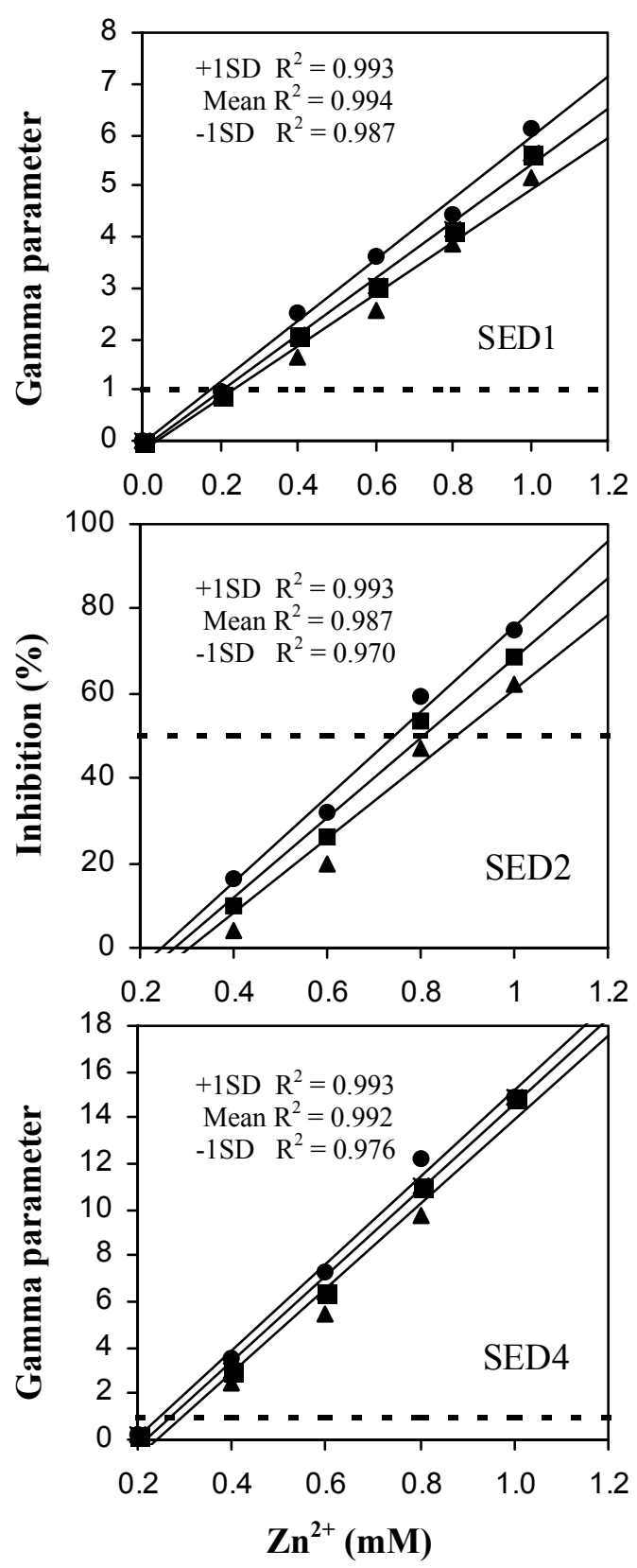

Figure 2. Relationships between the mean \pm standard deviation of gamma parameter and percent inhibition values with zinc ion concentrations for Bacillus sp. SED1, Salmonella sp. SED2 and Arthrobacter sp. SED 4. IC $C_{50}$ was calculated as mean \pm standard deviation from the linear curves. Symbols: Circle $=+1 S D$, Square $=$ mean, Triangle $=-1 S D$. 
a similar growth inhibition test, 0.1 and $0.5 \mathrm{mM}$ of zinc inhibited growth of Streptococcus faecalis by 8.77 and $18.42 \%$ respectively [4].

The 2-way ANOVA show that the dehydrogenase activity and its percentage inhibition varied significantly $(p<0.05)$ with bacteria type and the concentrations of zinc.

The result of the in vitro study indicated that $\mathrm{Zn}^{2+}$ is potentially toxic to the sediment bacteria of New Calaber River. Contamination and accumulation of $\mathrm{Zn}^{2+}$ in the sediment would likely impact negatively on carbon metabolism and respiratory activities of the bacterial strains. Since bacteria play important role in detrital breakdown and nutrient cycling, disturbances in their activity would result in general ecosystem stress.

Table 2. Threshold inhibitory concentrations of zinc against sediment bacterial strains

\begin{tabular}{lccc}
\hline Bacteria & \multicolumn{3}{c}{ Inhibitory concentrations $(\mathrm{mM})^{\mathrm{a}}$} \\
\cline { 2 - 4 } & $\mathrm{IC}_{20}$ & $\mathrm{IC}_{50}$ & $\mathrm{IC}_{100}$ \\
\hline & & & \\
Bacillus sp. SED1 & $0.071 \pm 0.019$ & $0.206 \pm 0.030$ & $1.442 \pm 0.062$ \\
Samonella sp. SED2 & $0.488 \pm 0.045$ & $0.807 \pm 0.066$ & $\mathrm{ND}$ \\
Arthrobacter sp. SED4 & $0.233 \pm 0.023$ & $0.273 \pm 0.024$ & $1.199 \pm 0.042$ \\
& & & \\
\hline
\end{tabular}

\section{REFERENCES}

[1] Aoyama, M. \& Nagumo, T. (1997): Effects of heavy metal accumulation in apple orchard soils on microbial biomass and activities. - Soil Science and Plant Nutrition 43: $821-831$.

[2] Bååth, E. (1989). Effects of heavy metals in soil on microbial processes and population: a review. - Water, Air and Soil Pollution 47: 335-379.

[3] Beard, S. J., Hughes, M. N., \& Poole, R. K. (1995): Inhibition of the cytochrome bd-terminated NADH oxidase system in Escherichia coli K-12 by divalent metal cations. - FEMS Microbiology Letters 131: 205 - 210.

[4] Bhattacherjee, J.W. (1986): Effect of cadmium and zinc on microbial adhesion, growth and metal uptake. Bulletin of Environmental Contamination and Toxicology 36: $396-400$.

[5] Bitton, G., Jung, K. \& Koopman, B. (1994): Evaluation of a microplate assay specific for heavy metal toxicity. - Archives of Environmental Contamination and Toxicology 27: $25-28$.

[6] Bryan, G.W. \& Langston, W.J. (1992): Bioavailability, accumulation and effects of heavy metals in sediments with special reference to United Kingdom estuaries: a review. - Environmental Pollution 76: 89 - 131.

[7] Chander, K., \& Brookes, P.C. (1995): Microbial biomass dynamics following addition of metal-enriched sewage sludges to a sandy loam. - Soil Biology and Biochemistry 27:1409-1421.

[8] Choudhury, R. \& Srivastava, S. (2001): Zinc resistance mechanisms in bacteria. - Current Science 8(7): 768 - 775. 
[9] Crapez, M., Neto, J.A.B. \& Bispo, M.G.S. (2003): Bacterial enzymatic activity and bioavailability of heavy metals in sediments from Boa Viagem Beach (Guanabara Bay). - Anuário do Instituto de Geociências - UFRJ 26: 60 - 68.

[10] Doelman, P. \& Haanstra, L. (1979): Effects of lead on the soil bacterial microflora. - Soil Biology and Biochemistry 11: 487 - 491.

[11] Doelman, P., Jansen, E., Michels, M., \& vanTil, M. (1994): Effects of heavy metals in soil on microbial diversity and activity as shown by the sensitivityresistance index, an ecologically relevant parameter. - Biology and Fertility of Soils 17: $177-184$.

[12] Griffiths, R. P. (1983): The importance of measuring microbial enzymatic functions while assessing and predicting lond-term anthropogenic perturbations. - Marine Pollution Bulletin 14: 162 - 165.

[13] Holt, J.G., Krieg, N.R., Sneath, P.H.A., Staley, J.T. \& Williams, S.T. (1994): Bergey's Manual of Determinative Bacteriology, 9th ed. Williams and Wilkins. Baltimore.

[14] Hornor, S. G. \& Hilt, B. A. (1985): Distribution of zinc-tolerant bacteria in stream sediment. - Hydrobiologia 128: 155 - 160.

[15] Horsfall Jr., M., \& Spiff, A.S. (2002): Distribution and partitioning of trace metals in sediments of the lower reaches of the New Calabar River, Port Harcourt, Nigeria. - Environmental Monitoring and Assessment 78: 309 - 326.

[16] Ji, G. \& Silver, S. (1995): Bacterial resistance mechanism for heavy metals of environmental concern. - Journal of Industrial Microbiology 14: 64-168.

[17] Kasahara, M. \& Anraku, Y. (1974): Succinate and NADH oxidase systems of Escherichia coli membrane vesicles: mechanism of selective inhibition of the system by zinc ions. - Journal of Biochemistry 76: 967 - 976.

[18] Kelly, J.J., \& Tate, R.L. (1998): Effects of heavy metal contamination and remediation on soil microbial communities in the vicinity of a zinc smelter. Journal of Environmental Quality 27: $609-617$.

[19] Kim, C-W., Koopman, B. \& Bitton, G. (1994): INT-Dehydrogenase activity test for assessing chloride and hydrogen peroxide inhibition of filamentous pure cultures and activated sludge. - Water Research 28(5): 1117 - 1121.

[20] Minz, D., Rosenburg, E. \& Ron, E.Z. (1996): Cadmium binding bacteria: Screening and characterization of new isolates and mutants. - FEMS Microbiology Letters 135:191 - 194.

[21] Morozzi, G., Ceni, G., Scardazza, F. \& Pitzurra, M. (1986): Cadmium uptake by growing of gram-positive and gram-negative bacteria. - Microbios 48: 27 - 35 .

[22] Nugent, C.E., Atchison, G.J., Nelson, D. W. \& McIntosh, A. W. (1980): The effects of heavy metals on microbial biomass in sediment of Palestine Lake. Hydrobiologia 70: $69-73$.

[23] Nweke, C.O., Okolo, J.C., Nwanyanwu, C.E. \& Alisi, C.S. (2006). Response of planktonic bacteria of New Calabar River to zinc stress. - African Journal of Biotechnology 5(8): $653-658$.

[24] Odokuma, L.O., \& Abah A.E. (2003): Heavy metal biosorption by three bacteria isolated from a tropical river. - Global Journal of Environmental Sciences 2(2): $98-101$.

[25] Odokuma, L.O. \& Ijeomah, S.O. (2003a): Tolerance of bacteria to toxicity of heavy meatals in the New Calabar River, Nigeria. - Global Journal of Environmental Sciences 2: $128-132$. 
[26] Odokuma, L.O. \& Ijeomah, S.O. (2003b): Seasonal changes in the heavy metal resistant bacterial population of the New Calabar River. - Global Journal of Pure and Applied Sciences 9: 425 - 433.

[27] Odokuma, L.O. \& Okpokwasili, G.C. (1997): Seasonal influences of the organic pollution monitoring of the New Calabar River, Nigeria. - Environmental Monitoring and Assessment 45: 43 - 56.

[28] Okpokwasili, G.C. \& Odokuma, L.O. (1993): Seasonal influences on inorganic anion monitoring of the New Calabar River, Nigeria. - Environmental Management 17: $491-496$.

[29] Odum, E.P. (1985): Trends expected in stressed ecosystems. - Bioscience 35: $419-422$.

[30] Pérez-Garcia, A., Codina, J.C., Cazorla, F.M. \& de Vicente, A. (1993): Rapid respirometric toxicity test: sensitivity to metals.- Bulletin of Environmental Contamination and Toxicology 50: $703-708$.

[31] Rogers, E.J \& Li, S.W. (1985): Effects of metals and other inorganic ions on soil microbial activity: soil dehydrogenase assay as a simple toxicity test. - Bulletin of Environmental Contamination and Toxicology 34: 858 - 865.

[32] Romero, M.C., Gatti, E. M. \& Bruno, D. E. (1999): Effects of heavy metals on microbial activity of water and sediment communities. - World Journal of Microbiology and Biotechnology 15: 179 - 184.

[33] Silver, S. and Misra, T. K. (1988): Plasmid mediated heavy metal resistances. Annual Review in Microbiology 42: 717-743.

[34] Slabbert, J.L. (1986): Improved bacteria growth test for rapid water toxicity screening. - Bulletin of Environmental Contamination and Toxicology 37:565 569. 